\title{
Total Phenolic and Flavonoid Contents and Antioxidant Activity of Kembang Bulan Leaves (Tithonia diversifolia (Hemsley) A. Gray)
}

\author{
Noer F. Rahman*, Nursamsiar, Megawati, Handayani, Christa A. M. Suares \\ Bagian Kimia Farmasi, Sekolah Tinggi Ilmu Farmasi Makassar, Jalan Perintis Kemerdekaan Km 13.7, Daya, Makassar, \\ 90242, Indonesia
}

Submitted 30 November 2021; Revised 05 December 2021; Accepted 05 December 2021; Published 30 December 2021 *Corresponding author: nrfziah.rahman@gmail.com

\begin{abstract}
Many plants are used ethnomedicinally for the treatment of disease and restoration of health. One of these medicinal plants is Tithonia diversifolia. This study aims to determine the phenolic and flavonoid contents and antioxidant activity using the DPPH method from the leaves of $T$. diversifolia. Extraction was carried out by the maceration method using $70 \%$ ethanol and ethyl acetate as solvents. Phenolic identification was carried out with $\mathrm{FeCl}_{3}$ reagent; the blackish green color formed indicates the presence of phenolic compounds. Identification of flavonoid was carried out using a reagent between magnesium powder and concentrated $\mathrm{HCl}$; the orange-red color formed indicated the presence of flavonoid. Determination of phenolic and flavonoid contents from extract of $T$. diversifolia leaves was carried out colorimetrically $\left(\mathrm{AlCl}_{3}\right.$ and $\left.\mathrm{NaCH}_{3}\right)$ using a UV-Vis spectrophotometer. The results showed that the total phenolic contents of the ethyl acetate and ethanolic extract of the $T$. diversifolia leaves was 1.28 and $1.37 \%$ GAE, respectively, while the total flavonoid contents was 2.21 and $3.41 \mathrm{mgQE} / \mathrm{g}$, respectively. Better antioxidant activity was shown by the ethanol extract with an IC50 value of 84.018 $\mu \mathrm{g} / \mathrm{ml}$. This information can be used to develop T. diversifolia leaves extract as an antioxidant agent because it has intense inhibition against free radicals by the DPPH method.
\end{abstract}

Keywords: Antioxidant, phenolic, flavonoid, Tithonia diversifolia

\section{Total Kandungan Fenolik dan Flavonoid serta Aktivitas Antioksidan Daun Kembang Bulan (Tithonia diversifolia (Hemsley) A. Gray)}

\begin{abstract}
Abstrak
Banyak tanaman yang digunakan secara etnomedisin untuk pengobatan penyakit serta pemulihan kesehatan. Salah satu tanaman obat tersebut adalah Tithonia diversifolia. Penelitian ini bertujuan untuk menentukan kandungan fenolik, flavonoid, serta aktivitas antioksidan dengan metode DPPH dari daun T. diversifolia. Ekstraksi dilakukan dengan metode maserasi menggunakan pelarut etanol $70 \%$ dan etil asetat. Identifikasi fenolik dilakukan dengan menggunakan metode Folin-Ciocalteu. Warna hijau kehitaman yang terbentuk menandakan adanya senyawa fenol. Identifikasi flavonoid dilakukan dengan pereaksi antara serbuk magnesium dan $\mathrm{HCl}$ pekat, warna jingga merah yang terbentuk menandakan adanya flavonoid. Penetapan kadar fenolik dan flavonoid dari ekstrak daun T.diversifolia dilakukan secara kolorimetri $\left(\mathrm{AlCl}_{3}\right.$ dan $\left.\mathrm{NaCH}_{3}\right)$ menggunakan spektrofotometer UV-Vis. Hasil penelitian menunjukkan kadar fenolik total ekstrak etil asetat dan etanol daun T.diversifolia adalah 1,28 dan 1,37\% EAG, begitu juga dengan kadar flavonoid total sebesar 2,21 dan 3,41 mgEK/g. Aktivitas antioksidan yang lebih baik ditunjukkan oleh ekstrak etanol dengan nilai IC50 sebesar 84,018 $\mu \mathrm{g} / \mathrm{ml}$. Informasi ini dapat digunakan untuk pengembangan ekstrak daun $T$. diversifolia sebagai agen antioksidan.
\end{abstract}

Kata Kunci: Antioksidan, fenolik, flavonoid, Tithonia diversifolia 


\section{Introduction}

Natural ingredients derived from plants have been widely used as traditional medicine and have long been used by the Indonesian people to treat various health problems such as diarrhea, malaria, inflammation-related diseases, degenerative diseases, etc. In addition to the benefits that have been used for generations, traditional medicines are considered cheaper and easier to obtain. ${ }^{1}$

Tithonia diversifolia (Hemsley) A. Gray or commonly called moonflower or kembang bulan is a type of plant that belongs to the Asteraceae family, which is known for its therapeutic properties: some of the primary uses are anthelmintic, antiinflammatory, astringent, cholesteric, antihemorrhagic, antimicrobial, antioxidant ${ }^{2}$, diuretic, analgesic, antispasmodic ${ }^{3}$, antiinflammatory, antimalarial ${ }^{4}$, and many other biological activities. In da Gama's research (2014), T. diversifolia flowers contain tannins, flavonoids, and phenols. ${ }^{5}$ The leaves are reported to contain sesquiterpene lactone taginin $\mathrm{C}$, diversifolin, diversifolin methyl ether, and thyrotundin as bioactive compounds against inflammation. Antioxidant potential of $T$. diversifolia aqueous extract on several pro-oxidants $\left(\mathrm{Fe}^{2+}\right.$ and sodium nitroprusside) induced lipid peroxidation in rat brain homogenates. ${ }^{2}$ Several phenolic compounds have antioxidant activity and exhibit tyrosinase inhibitory activity. ${ }^{6}$ Odeyemi et $\mathrm{al}^{7}$ using crude extract of $T$. diversifolia in methanol, ethanol, and water as antibacterial agent due to its antimicrobial effect on $P$. aeruginosa, Shigella sp., Enterococcus sp., E.coli, and Salmonella sp. However, several studies have described the action of essential oils from $T$. diversifolia against pathogens. The results of the phytochemical analysis of the aqueous extract of $T$. diversifolia revealed the presence of phenols, saponins, alkaloids, cyanogenic glycosides, tannins, organic acids, and resins. As well as having strong antioxidant activity from water extracts and ethanol extracts. $^{8}$

Phenolic and flavonoid are the main groups of secondary metabolites in plants and play a crucial role in antioxidant activity. ${ }^{9}$
The greater the content of the phenol group of compounds, the greater the antioxidant activity. Several studies on the antioxidant activity of phenolic compounds stated that their structure contributed to their activity. The structural activity of phenolic groups depends on the number and location of hydroxyl groups that play a role in scavenging free radicals. Strong antioxidant abilities are due to the presence of phenolic groups that donate electrons or are conjugated with metal ions. ${ }^{10}$ Phenolic compounds have been known to have various biological activities such as antioxidants through mechanisms as reducing agents, free radical scavengers, metal chelating agents, reducing the formation of singlet oxygen and electron donors. ${ }^{11}$ Phenolic compounds can be categorized into different groups such as flavonoids, phenolic acids, stilbenes, and lignans based on the number of carbon molecules and the complexity of their structure. ${ }^{9}$ Each phenolic group has unique attributes due to its specific molecular structure.

This study aimed to determine the total flavonoid and phenolic contents of extracts of $T$. diversifolia leaves and their antioxidant activity using the DPPH method (2,2-diphenyl-1-picryl-hydrazyl). Testing was carried out with two kinds of solvents, $70 \%$ ethanol and ethyl acetate. The aim was to find out which type of solvent was better at attracting compounds that have better antioxidant activity of $T$. diversifolia leaves extract

\section{Materials and methods}

\subsection{Tools and materials}

Freshly $T$. diversifolia leaves were collected from Tanete District, West Riattang, Bone District, South Sulawesi. The sample was cleaned with running water and separated from the stalk. Then chopped into small pieces and dried to become dried simplicia. The mashed dried simplicia was extracted using maceration method with $70 \%$ ethanol (EMSURE®) and ethyl acetate (J.T.Baker ${ }^{\circledR}$ ) for each $3 \times 24$ hours. The result of maceration was filtered, and the residue was remacerated with the same solvent. The 
filtrate was collected and evaporated using rotary evaporator (IKA® ${ }^{\circledR}$ Rv 10 Basic) to obtain sticky extract.

\subsection{Phenolic Compound Test}

\subsubsection{Qualitative Test}

A total of $1 \mathrm{ml}$ of the extract solution was put into a test tube and about 2-3 drops of $\mathrm{FeCl}_{3}$ solution were added. The presence of phenolic compounds show intense green, red, purple, blue, or black color. ${ }^{12}$

\subsubsection{Total Phenolic Contents (TPCs)}

Determination of TPCs of $T$. diversifolia leaves extract using the Folin-Ciocalteu method and gallic acid as standard solution. Concentration variations of standard gallic acid solution of $100 \mu \mathrm{g} / \mathrm{ml}(0.2 ; 0.4 ; 0.6 ; 0.8$; and $1 \mathrm{ml})$ were made and $0.5 \mathrm{ml}$ of FolinCiocalteau reagent was added to each flask. Then $2 \mathrm{ml}$ of $1 \% \mathrm{Na}_{2} \mathrm{CO}_{3}$ solution was added to the mixture and the volume was made up to $5 \mathrm{ml}$ with distilled water, incubated for 60 minutes. The absorbance was measured at $735 \mathrm{~nm}$ using UV-Vis spectrophotometer (Shimadzu® ${ }^{\circledR}$ UV-1800). Total phenol was calculated as \% Gallic Acid Equivalent (GAE) ${ }^{13}$

\subsection{Flavonoid Compound Test}

\subsubsection{Qualitative Test}

A volume of $2 \mathrm{ml}$ of the extract was put in a test tube. Then, $0.5 \mathrm{ml}$ concentrated $\mathrm{HCl}$ and a few grains of magnesium powder (cyanidin test) were added. The appearance of orange to red color indicates the presence of flavonoids. ${ }^{1}$

\subsubsection{Total Flvonoid Contents (TFCs)}

The TFCs of each extract was investigated using the aluminium chloride colorimetry method adapted from Koley $(2018)^{14}$ with slight changes. In brief, about $1.5 \mathrm{ml}$ of each extract solution was pipetted from the $1000 \mathrm{ppm}$ main solution, then 0.1 $\mathrm{ml}$ of $10 \% \mathrm{AlCl}_{3}$ was added, $0.1 \mathrm{ml}$ of $1 \mathrm{M}$ $\mathrm{CH}_{3} \mathrm{COONa}$ was mixed and the volume was made up to $5 \mathrm{ml}$ using ethanol. Then it was incubated for 30 minutes in the dark at room temperature. The absorbance was measured at $425 \mathrm{~nm}$ using UV-Vis spectrophotometer (Shimadzu® UV-1800). Determination of the TFCs of the extract expressed in mg Quercetin Equivalent (QE)/g dried extract. ${ }^{11}$

\subsection{Determination of Antioxidant Activity using DPPH Assay \\ A stock solution of $0.4 \mathrm{mmol}$ DPPH was} prepared, and a series of concentrations of $T$. diversifolia leaves extract samples were made for ethanol extract's samples $(20,40,60,80$, and $100 \mu \mathrm{g} / \mathrm{ml})$ and ethyl acetate's $(100,150$, $200,250$, and $300 \mu \mathrm{g} / \mathrm{ml})$. Each concentration series was pipetted $1 \mathrm{ml}$ and added $1 \mathrm{ml}$ of DPPH, then made up to $5 \mathrm{ml}$ of ethanol. The process was repeated thrice, and then incubated for 30 minutes at room temperature. The absorbance was measured using a UVVis spectrophotometer (Shimadzu ${ }^{\circledR}$ UV$1800)$ at $515 \mathrm{~nm}$. A blank solution was also prepared as a control. L-Ascorbic acid (vitamin C, as a standard for antioxidant analysis) was dissolved in absolute ethanol to a concentration of $100 \mu \mathrm{g} / \mathrm{ml}$. L-Ascorbic acid solution was freshly prepared with varian concentrations $(12,18,24,30,36 \mu \mathrm{g} / \mathrm{ml})$. All the tests were performed at least in triplicate. The IC50 value for DPPH radical scavenging is known from the linear regression graph plotted between sample concentration and $\%$ inhibition. ${ }^{15}$

\section{Result}

3.1. Extraction Results and Identification of Phenol and Flavonoid Contents

Extraction results of 300 grams of dried simplicia leaves of T. diversifolia with $70 \%$ ethanol and ethyl acetate solvent by maceration method as showed in Table 1. Furthermore, qualitative identification of phenolic and flavonoid compounds were carried out. The results of the ethanolic and ethyl acetate extracts of the leaves of T. diversifolia showed positive results containing phenolic and flavonoid compounds showed in Table 2. It is characterized by a red-orange (flavonoid) and green-black (phenolic) color change. Based on the literature, $T$. diversifolia contains various chemical compounds, including tannins, flavonoids, phenols, sesquiterpene 
Table 1. Yield of Ethanol and Ethyl Acetate Extract from T. diversifolia (Hemsley) A. Gray)

\begin{tabular}{cccc}
\hline Extract & $\begin{array}{c}\text { Weight of sticky } \\
\text { extract }(\mathbf{g})\end{array}$ & $\begin{array}{c}\text { Weight of dried extract } \\
(\mathbf{g})\end{array}$ & Yield (\%) \\
\hline Ethanol & 88.77 & 300 & 29.59 \\
Ethyl acetate & 47.21 & 300 & 15.74 \\
\hline
\end{tabular}

Table 2. Qualitative Identification of Phenolic and Flavonoid Compounds of Extract of T. diversifolia Leaves

\begin{tabular}{ccccc}
\hline \multirow{2}{*}{ Extract } & \multicolumn{2}{c}{ Color observation } & \multicolumn{2}{c}{ Results } \\
& FeCl3 & Mg+HCl & Phenolic & Flavonoid \\
\hline Ethanol & Blackish green & Orange red & Positive & Positive \\
Ethyl acetate & Blackish green & Orange & Positive & Positivie \\
\hline
\end{tabular}

lactone taginin $\mathrm{C}$, diversifolin, diversifolin methyl ether, and thyrotundine, etc. ${ }^{2}$

Determination of the TPCs using a linear regression equation from a standard solution of gallic acid as showed in Figure 1. The results obtained (showed in Table 3) after measuring the absorbance of the sample by triplication, the ethyl acetate extract with TPCs value of $1.28 \pm 0.11 \% \mathrm{GAE}$, have smaller total phenolic contents than ethanol of $1.37 \pm 0.03 \%$ GAE.

Table 4 shows the results of the measurement of the test sample for determining the total flavonoid content made as many as 3 replications. Determination of TFCs using linear regression equation of standard quercetin curve (see Figure 2)with the average value of flavonoid content of ethanol extract was $3.41 \pm 0.06 \mathrm{mgQE} / \mathrm{g}$, and ethyl acetate extract was $2.21 \pm 0.05 \mathrm{mgQE} / \mathrm{g}$ (Table 4). From the results, it can be seen that the ethanol extract has a higher total flavonoid content than the ethyl acetates extract. That results obtained were in with the results obtained at TPCs (Table 3).
The results showed that $70 \%$ ethanol extract gave high inhibition, indicated by a smaller IC50 value of $84.018 \mu \mathrm{g} / \mathrm{ml}$ than ethyl acetate extract with an IC50 value of 311.346 $\mu \mathrm{g} / \mathrm{ml}$, which gave weak inhibition.

\section{Discussion}

The extraction process using the maceration method produced a yield value of $29.56 \%$ for the ethanol extract and $15.73 \%$ for the ethyl acetate extract. The difference in value is influenced by many factors, including the concentration and type of solvent. The success of the separation process depends on the difference in the solubility of the components to be separated. ${ }^{16}$ Polar compounds will tend to dissolve in solvents that are also polar, and vice versa. These results also indicate that increasing the water consentration in the solvent enhances extraction yield. The combined use of water and organic solvent may facilitate the extraction of chemicals that are soluble in water and/or organic solvent. In addition to the type of solvent, sample size also affects

Table 3. Total Phenolic Contents Gallic Acid Equivalent (GAE) of Ethanol and Ethyl Acetate Extracts of $T$. diversifolia leaves

\begin{tabular}{ccccc}
\hline Extract & Replication & Absorbance & TPCs (\%) & Average TPCs (\%) \\
\hline \multirow{3}{*}{ Ethanol } & 1 & 0.3211 & 1.4 & \\
& 2 & 0.3092 & 1.3 & $1.37 \pm 0.03$ \\
& 3 & 0.3102 & 1.3 & \\
Ethyl acetate & 1 & 0.3071 & 1.3 & \\
& 2 & 0.3095 & 1.4 & $1.28 \pm 0.11$ \\
\hline
\end{tabular}




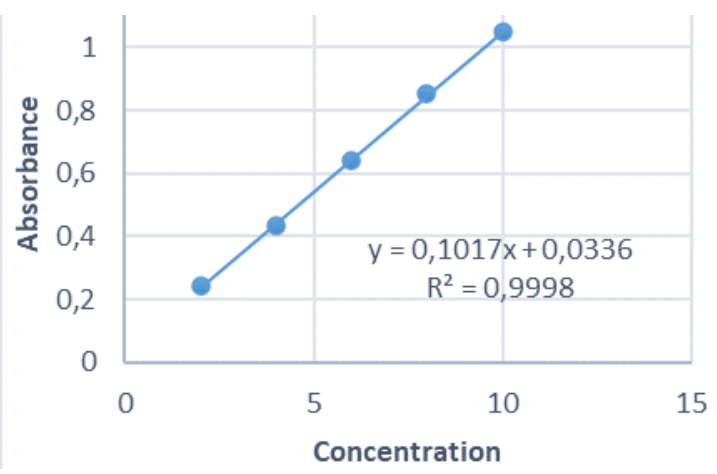

Figure 1. Standard curve of Gallic acid

the amount of yield. The smaller the surface area of the sample will further expand the contact and increase the interaction with the solvent. ${ }^{17}$

The purpose of the preliminary test was to provide an overview of the class of compounds contained in the ethanol and ethyl acetate extracts of $T$. diversifolia leaves. The compounds identified were flavonoid by adding $\mathrm{HCl}$ and magnesium powder. The purpose of adding magnesium and $\mathrm{HCl}$ powder was to reduce the benzopyron core in the flavonoid structure so that the color changes to orange and red. ${ }^{13}$

The total phenolic contents in the extract was determined using the Agbor method (2014). ${ }^{18}$ This method was used because the operation was simple compared to other instruments and the use of Folin reagent, which can form a solution with phenolic compounds so that the absorbance can be measured. The principle of the Folin-Ciocalteau method is the formation of a complex blue compound that can be measured at wavelength of $765 \mathrm{~nm}$. This reagent oxidizes phenolics (alkali salts) or phenolic-hydroxy groups reducing heteropoly

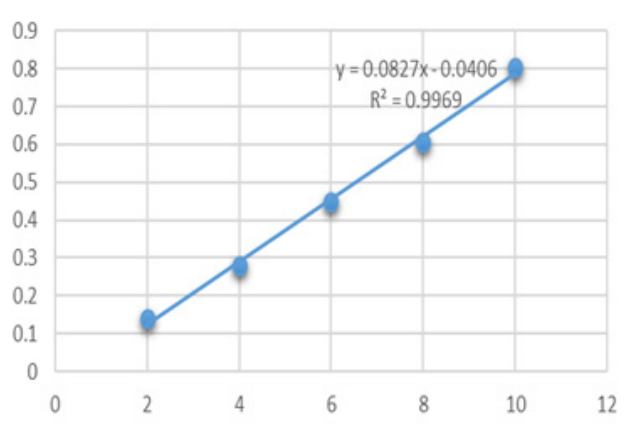

Figure 2. Standard curve of Quercetin

acids (phosphomolybdate-phosphotungstic) present in the Folin-Ciocalteau reagent to a molybdenum-tungsten complex. Phenolic compounds react with Folin-Ciocalteau reagent only in an alkaline environment to cause the dissociation of protons in phenolic compounds into phenolic ions. To make alkaline conditions used $\mathrm{Na}_{2} \mathrm{CO}_{3} 7.5 \%$. The hydroxyl group in phenolic compounds reacts with the Folin-Ciocalteau reagent to form a blue-colored tungsten molybdenum complex which a spectrophotometer can detect. The greater the concentration of phenolic compounds, the more phenolic ions that will reduce heteropoly acid (phosphomolybdatephosphotungstic) to a molybdenum-tungsten complex so that the resulting blue color is more intense. ${ }^{19}$

Determination of totalflavonoidcontents was carried out using the colorimetric method with UV-Vis spectrophotometric instrument. In this method, $\mathrm{AlCl}_{3}$ and $\mathrm{NaCH}_{3}$ are used as reagents. The reaction between $\mathrm{AlCl}_{3}$ with flavonoid group compounds forms a complex between paired hydroxyl groups and ketones or neighboring hydroxyl groups. In addition, $\mathrm{CH}_{3} \mathrm{COONa}$ also serves to detect 7-hydroxyl

Table 4. Total Flavonoid Contents Quercetin Equivalent (QE) of Ethanol and Ethyl Acetate of $T$. diversifolia Leaves

\begin{tabular}{ccccc}
\hline Extract & Replication & Absorbance & $\begin{array}{c}\text { TFCs } \\
(\mathbf{m g Q E} / \mathbf{g})\end{array}$ & $\begin{array}{c}\text { Average TFCs } \\
(\mathbf{m g Q E} / \mathbf{g})\end{array}$ \\
\hline \multirow{3}{*}{ Ethanol } & 1 & 0.525 & 3.419 & \\
& 2 & 0.513 & 3.347 & $3.41 \pm 0.06$ \\
\multirow{2}{*}{ Ethyl acetate } & 3 & 0.534 & 3.474 & \\
& 1 & 0.328 & 2.228 & \\
& 2 & 0.315 & 2.149 & $2.21 \pm 0.05$ \\
\hline
\end{tabular}


groups. The ethanol and ethyl acetate extracts of the leaves of kembang bulan (T. diversifolia (Hemsley) A. Gray) were then calculated for the flavonoid content using UV-Vis spectrophotometer with a standard solution of quercetin. The analysis of flavonoid was carried out using UV-Vis spectrophotometry because it is commonly used for quantitative and qualitative analysis of flavonoids. Also, flavonoids contain a conjugated aromatic system showing strong absorption bands in the ultraviolet and visible light spectrum. While the selection of quercetin was a standard solution because it is one of the most widely distributed compounds, quercetin is a flavonoid of the flavonol group that has a keto group at C-4 and has a hydroxyl group on the $\mathrm{C}-3$ or $\mathrm{C}-5$ atom which is neighboring of flavones and flavonols.

Flavonoid compounds are polyphenol's main components, which have been studied extensively as one of the most important antioxidant agents in many medicinal plants. This antioxidant activity is mainly based on its redox properties essential for the adsorption and neutralization of free radicals, quenching of single and triple oxidants, or decomposition of peroxides. ${ }^{20}$

The levels of TPCs and TFCs in the ethanol extract were higher than in the ethyl acetate extract, this might be influenced because more ethanol extraction results were obtained. It may also be caused by the possible complex formation of some phenolic compounds in the extract that are soluble in $70 \%$ ethanol. These phenolic compounds may possess more phenol groups or have higher molecular weight than the phenolics in the ethyl acetate extract. Based on the results of TPCs, the best extracting solvent was $70 \%$ ethanol. ${ }^{21}$

The antioxidant properties of the extract further illustrate the potential role of flavonoid antioxidants in reducing cellular oxidative stress. The value of reducing power obtained is relatively high. This can be an indication that plant extracts have antioxidant potential. The higher the absorbance value of the extract, the higher the antioxidant capacity. ${ }^{2}$ The effectiveness of antioxidants is generally influenced by several factors, including their structural features, concentration, temperature, type of oxidation substrate, and physical state of the system, as well as the presence of pro-oxidant and synergists. ${ }^{21}$

In the antioxidant test of $T$. diversifolia leaf extract using the DPPH method, the IC50 of ethyl acetate extract was $311.346 \mu \mathrm{g} / \mathrm{ml}$ which was included in the weak category. In comparison, the ethanol extracthadantioxidant potential with an IC50 value of $84.018 \mu \mathrm{g} / \mathrm{ml}$ which was included in the strong category. The results of Antioxidant activities of $T$. diversifolia can be seen in Table 5 and 6 leaves while Table 7 shows the antioxidant activity of vitamin C. Table 8 shows the strength category of antioxidant activity). The lower the IC50 value, the lower the concentration needed to reduce free radical activity, so the results are considered better. The higher IC50 value in the ethanol extract is probably due to phenolic compounds playing an important role in scavenging DPPH radicals by donating electrons or hydrogen to stabilize radicals. ${ }^{21}$ This finding follows several previous studies on the positive correlation between total phenol content and some plant's DPPH free radical scavenging ability.

Table 5. Antioxidant (DPPH) of Ethyl Acetate Extract of T. diversifolia Leaves

\begin{tabular}{ccccc}
\hline $\begin{array}{c}\text { Concentration } \\
(\boldsymbol{\mu g} / \mathbf{m l})\end{array}$ & $\begin{array}{c}\text { Average of } \\
\text { absorbance }\end{array}$ & $\begin{array}{c}\text { Inhibition } \\
(\boldsymbol{\%})\end{array}$ & $\begin{array}{c}\text { IC50 } \\
(\boldsymbol{\mu g} / \mathbf{m l})\end{array}$ & Category \\
\hline 100 & 0.511 & 25.19 & & \\
150 & 0.477 & 30.21 & & \\
200 & 0.429 & 37.18 & 311.346 & Weak \\
250 & 0.382 & 44.10 & & \\
300 & 0.358 & 47.56 & & - \\
Blank & 0.684 & - & - & \\
\hline
\end{tabular}


Table 6. Antioxidant (DPPH) of Ethanol Extract of T. diversifolia leaves

\begin{tabular}{ccccc}
\hline $\begin{array}{c}\text { Concentration } \\
(\boldsymbol{\mu g} / \mathbf{m l})\end{array}$ & $\begin{array}{c}\text { Average of } \\
\text { absorbance }\end{array}$ & $\begin{array}{c}\text { Inhibition } \\
(\mathbf{\%})\end{array}$ & $\begin{array}{c}\text { IC50 } \\
(\boldsymbol{\mu g} / \mathbf{m l})\end{array}$ & Category \\
\hline 20 & 0.572 & 16.37 & & \\
40 & 0.477 & 22.07 & & \\
60 & 0.429 & 36.69 & 84.018 & Strong \\
80 & 0.533 & 22.07 & & \\
100 & 0.358 & 58.47 & & - \\
Blank & 0.684 & - & - & \\
\hline
\end{tabular}

Table 7. Antioxidant (DPPH) of Vitamin C

\begin{tabular}{ccccc}
\hline $\begin{array}{c}\text { Concentration } \\
(\boldsymbol{\mu g} / \mathbf{m l})\end{array}$ & $\begin{array}{c}\text { Average of } \\
\text { absorbance }\end{array}$ & $\begin{array}{c}\text { Inhibition } \\
(\mathbf{\%})\end{array}$ & $\begin{array}{c}\text { IC50 } \\
(\boldsymbol{\mu g} / \mathbf{m l})\end{array}$ & Category \\
\hline Blank & 0,637 & - & - & - \\
$12 \mu \mathrm{g} / \mathrm{mL}$ & 0,469 & 26,373 & & \\
$18 \mu \mathrm{g} / \mathrm{mL}$ & 0,368 & 42,229 & & \\
$24 \mu \mathrm{g} / \mathrm{mL}$ & 0,279 & 56,200 & 20,382 & Very strong \\
$30 \mu \mathrm{g} / \mathrm{mL}$ & 0,197 & 69,073 & & \\
$36 \mu \mathrm{g} / \mathrm{mL}$ & 0,106 & 83,359 & & \\
\hline
\end{tabular}

Table 8. Strength Category of Antioxidant Activity ${ }^{22}$

\begin{tabular}{cc}
\hline Category & Concentration $(\boldsymbol{\mu g} \mathbf{m} \mathbf{m l})$ \\
\hline Very strong & $<50$ \\
Strong & $50-100$ \\
Moderate & $101-150$ \\
Weak & $151-200$ \\
\hline
\end{tabular}

\section{Conclusion}

In conclusion, this study aims to determine the phenolic and flavonoid contents and antioxidant activity using the DPPH method from the leaves of $T$. diversifolia. The results showed that the Total Phenolic Contents of the ethanolic and ethyl acetate extract of the $T$. diversifolia leaves was 1.37 and $1.28 \%$ GAE respectively, and the Total Flavonoid Contents was 3.41 and $2.21 \mathrm{mgQE} / \mathrm{g}$ respectively. The antioxidant activity was shown by the ethanol extract with an IC50 value of $84.018 \mu \mathrm{g} / \mathrm{ml}$. The results will provide important information for the future study to develop $T$. diversifolia leaves extract as an antioxidant agent because it has intense inhibition against free radicals by the DPPH method.

\section{References}

1. Wahyuni M, Saleh C, Kartika R. Uji
Toksisitas (Brine Shrimp Lethality Test) dan Uji Aktivitas Antibakteri Daun Kembang Bulan (Tithonia diversifolia A. Gray) terhadap Bakteri Staphylococcus aureus dan Escherichia coli. J Kim Mulawarman. 2015; 12(2): 79-82.

2. Ojo OA, Ojo AB, Ajiboye BO, Olaiya $O$, Okesola MA, Boligon AA, et al. HPLC-DAD Fingerprinting Analysis, Antioxidant Activities of Tithonia diversifolia (Hemsl.) A. Gray Leaves and Its Inhibition of Key Enzymes Linked to Alzheimer's Disease. Toxicol Reports. 2018; 5(October 2017): 585-92.

3. Farias ALF, Rodrigues ABL, Martins RL, Rabelo É de M, Farias CWF, de Almeida SSM da S. Chemical Characterization, Antioxidant, Cytotoxic and Microbiological Activities of The Essential Oil of Leaf of Tithonia diversifolia(Hemsl)A. Gray (Asteraceae). 
Pharmaceuticals. 2019;12(1).

4. Alkandahri MY, Subarnas A. Review: Kandungan Senyawa Kimia dan Aktivitas Farmakologi Ekstrak Daun Kembang Bulan (Tithonia diversifolia (Hemsley) a. Gray) sebagai Antimalaria. Farmaka. 2017;15(3): 170-86.

5. Gama RM da, Guimarães M, de Abreu LC, Armando-Junior J. Phytochemical screening and antioxidant activity of ethanol extract of Tithonia diversifolia (Hemsl) A. Gray dry flowers. Asian Pac J Trop Biomed. 2014 Sep 1; 4(9): 740-2.

6. Pantoja Pulido KD, Colmenares Dulcey AJ, Isaza Martínez JH. New Caffeic Acid Derivative from Tithonia diversifolia (Hemsl.) A. Gray Butanolic Extract and Its Antioxidant Activity. Food Chem Toxicol. 2017 Nov 1; 109(2): 1079-85.

7. Agidigbi TS, Odeyemi AT, Adefemi SO, Fasuan SO. Antibacterial Activities of Crude Extracts of Tithonia Diversifolia Against Common Environmental Pathogenic Bacteria. Exp Int J Sci Technol. 2017; 20(4): 1421-6.

8. Tania PM, Castilo BD del, Serrao PCD, Lobato RAB, Silva RR da, Oliveira PF de, et al. Antioxidant Effect of Plant Extracts of The Leaves of Tithonia diversifolia (Hemsl.) A. Gray on The Free Radical DPPH. J Chem Pharm Res. 2016;8(8): 1182-9.

9. Hoda M, Hemaiswarya S, Doble M. Role of Phenolic Phytochemicals in Diabetes Management. Role of Phenolic Phytochemicals in Diabetes Management. Singapore: Springer; 2019. 13-44 p.

10. Hoyweghen L Van, Beer T De, Deforce D, Heyerick A. Phenolic Compounds and Anti-oxidant Capacity of Twelve Morphologically Heterogeneous Bamboo species. Phytochem Anal. 2012;23(5): 433-43.

11. Nur S, Sami FJ, Awaluddin A, Afsari MIA. Korelasi Antara Kadar Total Flavonoid dan Fenolik dari Ekstrak dan Fraksi Daun Jati Putih (Gmelina Arborea Roxb.) Terhadap Aktivitas Antioksidan. J Farm Galen (Galenika J Pharmacy). 2019;5(1): 33-42.
12. Tahir M, Muflihunna A, Syafrianti S. Penentuan Kadar Fenolik Total Ekstrak Etanol Daun Nilam (Pogostemon cablin Benth.) dengan Metode Spektrofotometri UV-Vis. J Fitofarmaka Indones. 2017;4(1): 215-8.

13. Nur S, Mubarak F, Jannah C, Winarni DA, Rahman DA, Hamdayani LA, et al. Total Phenolic and Flavonoid Compounds, Antioxidant and Toxicity Profile of Extract and Fractions of Paku Atai Tuber (Angiopteris ferox Copel). Food Res. 2019; 3(6): 734-40.

14. Koley TK, Maurya A, Tripathi A, Singh B., Singh M, Buthia T., et al. Antioxidant Potential of Commonly Consumed Underutilized Leguminous Vegetables. Int J Veg Sci. 2018; 25(4):3 62-72.

15. Kaur R, Kaur J, Kaur M, Kalotra V, Chadha P, Kaur A, et al. An Endophytic Penicillium Oxalicum Isolated from Citrus limon Possesses Antioxidant and Genoprotective Potential. J Appl Microbiol. 2020; 128(5): 1400-13.

16. Susanty S, Bachmid F. Perbandingan Metode Ekstraksi Maserasi dan Refluks Terhadap Kadar Fenolik dari Ekstrak Tongkol Jagung (Zea mays L.). J Konversi. 2016; 5(2): 87.

17. Sineke FU, Suryanto E, Sudewi S. Penentuan Kandungan Fenolik dan Sun Protection Factor (SPF) dari Ekstrak Etanol dari Beberapa Tongkol Jagung (Zea mays L.). Pharmacon. 2016;5(1):275-83.

18. Agbor GA, Vinson JA, Donnelly PE. International Journal of Food Science, Nutrition and Dietetics (IJFS) FolinCiocalteau Reagent for Polyphenolic Assay Description of Folin Ciocalteau Reagent. Int J Food Sci Nutr Diet. 2014; 3: 147-56.

19. Alfian R, Susanti H. Penetapan Kadar Fenolik Total Ekstrak Metanol Kelopak Bunga Rosella Merah (Hibiscus sabdariffa Linn) dengan Variasi Tempat Tumbuh Secara Spektrofotometri. Pharmaciana. 2012; 2(1).

20. Nurcholis W, Sya'bani Putri DN, Husnawati H, Aisyah SI, Priosoeryanto BP. Total flavonoid Content and 
Antioxidant Activity of Ethanol and Ethyl Acetate Extracts from Accessions of Aamomum compactum fruits. Ann agric sci. 2021; 66(1): 58-62.

21. Do QD, Angkawijaya AE, Tran-Nguyen PL, Huynh LH, Soetaredjo FE, Ismadji S, et al. Effect of Extraction Solvent on Total Phenol Content, Total Flavonoid Content, and Antioxidant Activity of Limnophila aromatica. J Food Drug Anal. 2014 Sep 1;22(3): 296-302.

22. Batubara R, Nurminah M, Hanum T, Surjanto S. Potency of Gaharu Leaves that Grows Naturally and Cultivately as Raw Material of Antioxidant-Rich Tea. 2019; (1). 